„Ante Portas - Studia nad Bezpieczeństwem”

2018, $\mathrm{Nr} 2(11)$

DOI: $10.33674 / 2201826$

\title{
Krzysztof SURDYK
}

Polska

\section{POLEMIKA Z LESZKIEM SYKULSKIM DOTYCZĄCA RECENZJI KSIĄŻKI „KONFLIKT UKRAIŃSKI W ROZGRYWKACH GEOPOLITYCZNYCH”}

Poproszono mnie, abym w ramach polemiki ustosunkował się do recenzji mojej książki „Konflikt ukraiński w rozgrywkach geopolitycznych”, przygotowanej przez pana dra Leszka Sykulskiego. Recenzja jest niezwykle krytyczna i w zasadzie oprócz kilku ogólnych stwierdzeń o wartości poszczególnych rozdziałów, deprecjonuje wartość publikacji. No cóż, jak zwykle to czytelnik ma prawo do ostatecznego osądu. Korzystając jednak ze stworzonej mi przez redakcję Ante Portas - Studia nad Bezpieczeństwem możliwości postanowiłem ustosunkować się to tez wyrażonych w recenzji.

Recenzent zarzuca publikacji szereg braków. Pomimo iż cały rozdział poświęcam wojnom informacyjnym twierdzi, że brakuje mu $\mathrm{w}$ niej zagadnień zwiazanych $z$ geopolityka informacyjna. Ponadto wg recenzenta publikacja powinna rozwinąć temat wptywu geopolityki na rosyjskie myślenie strategiczne po 1991 r., czy rozwoju świadomości geopolitycznej rosyjskich elit względem Ukrainy. Brakuje w niej również zagadnień związanych z geopolityką Morza Czarnego i szczegółowego opisu samego konfliktu na Ukrainie itp. Recenzent sugeruje nawet, że tytuł publikacji jest niewłaściwy (faktycznie tytuł był wielokrotnie dyskutowany i uzgadniany z wydawnictwem).

Odnoszę wrażenie, że w swojej recenzji dr Sykulski przedstawił swego rodzaju wzór, według którego powinienem napisać swoją książkę, a która powinna mieć kształt monografii lub pracy naukowej z zakresu geopolityki. Tymczasem, chciałbym oświadczyć, że książki w kształcie, w jakim proponuje mi recenzent, nigdy nie zamierzałem napisać. Rzeczywistym celem jej napisania, co wyraziłem jasno we wstępie, było rzucenie więcej światła na mechanizmy rzqdzace wspótczesnym światem, o których wiemy przerażająco mało, w oparciu o własną wiedzę i liczne materiały analityczne i faktograficzne (ponad 100 pozy- 
cji literatury). Użycie w tytule książki słowa „geopolitycznych” nie oznacza, że książka ma się mieścić w nakreślonym przez recenzenta szablonie.

$\mathrm{Z}$ recenzji dowiedziałem się również, że publikacja pozbawiona jest jakiejkolwiek bazy teoretycznej, co recenzent uzasadnia brakiem thumaczenia przeze mnie takich pojęć, jak „,geopolityka”, „rywalizacja geopolityczna” czy „, wreszcie konflikt ukraiński”. Co prawda nie słyszałem o tym, aby autor był obowiązany tłumaczyć, pewne intuicyjnie rozumiane pojęcia, ale dla porządku sięgnąłem po znaną publikację Zbigniewa Brzezińskiego, z zakresu geopolityki „Wielka Szachownica”, aby zobaczyć, jak robią to najlepsi. Jakoś nie znalazłem w niej ani definicji, ani tłumaczenia powyższych kwestii, chociaż autor używa ich w wielu kontekstach.

Recenzent zarzuca mi również brak jasnej operacjonalizacji celu $i$ charakteru książki. W tym przypadku odnoszę wrażenie, że dosyć pobieżnie przeczytał moją książkę, ponieważ cel, jaki przyświecał jej napisaniu został sformułowany już we wstępie i na początku I rozdziału. Tam również określono (cytując słowa Johna Sawersa byłego szefa MI-6) kryzys na Ukrainie, jako symptom w stosunkach Rosji z Zachodem, a nie istotę problemu. Z tego też powodu zasadnicza część książki poświęcona jest rozgrywkom głównych graczy na arenie międzynarodowej, których zrozumienie może pomóc we właściwym (oczywiście w mojej ocenie) zrozumieniu konfliktu ukraińskiego. Mam nadzieję, że poprawnie użyłem wyrażenia „konflikt ukraiński”, bo recenzent uważa, że jest duża różnica między stwierdzeniami „,konflikt na Ukrainie”, „,konflikt ukraiński" itp.

Na zakończenie chciałbym się jeszcze odnieść do kwestii szczegółowej kilku rażących błędów merytorycznych $w$ odniesieniu do geopolityki, jakie $\mathrm{w}$ ocenie recenzenta popełniłem w rozdziale I. Pierwszy zarzut dotyczy daty wyróżnienia Heartlandu przez H. Mackindera. Poniżej przedstawiam dwa teksty dot. tej kwestii: cytat $\mathrm{z}$ recenzowanej książki i tekst autorstwa recenzenta:

- Dla swego rodzaju przypomnienia, a dla mniej obeznanych z geopolity$k a$ - uświadomienia, zaczać należałoby od H. Mackindera, który w 1904 roku stworzyt pierwsza geopolityczna regionalizację świata. Mackinder uważat, że masa ladowa i ogromne zasoby naturalne i ludzkie tzw. Heartlandu /część Eurazji - Rosja, Europa Wschodnia, Azja Centralna, Kaukaz i Chiny Zachodnie/ predysponuja go do odgrywania decydujacej roli w historii i rozwoju geopolitycznym świata. (s. 13 -14 recenzowanej książki).

- Kluczowa koncepcja, która stworzyt była teoria potegi kontynentalnej, zwana potocznie koncepcja Heartlandu. Koncepcja ta ewoluowała przez lata, stąd jej rozwój i prezentacje przedstawia się $w$ trzech etapach. Po raz pierwszy Halford Mackinder wytożyt swoja teorię $w$ 
kwietniu 1904 r. w artykule pt. The Geographical Pivot of History (,,Geograficzna oś historii”) na tamach pisma „Geographical Journal". Stworzyt wówczas swój własny geopolityczny model przestrzenny globu ziemskiego. (Leszek Sykulski, GEOPOLITYKA. Skrypt dla początkujących).

Przedstawiając skrótowo, na potrzeby książki, koncepcję Heartlandu H. Mackindera, nie wnikałem oczywiście w szczegóły dotyczące historii jej powstawania. Istotna była data powstania samej koncepcji, co jak przyznaje recenzent nastąpiło w 1904 r. To, że sama nazwa Heartland powstała później, jak widać nie przeszkadza recenzentowi, aby stwierdzić w swojej książce, że koncepcja zwana potocznie koncepcja Heartlandu ...po raz pierwszy wyłożona została w 1904 r.

Drugi „rażący” błąd dotyczy pojęcia World Island (nie Island World), które wg recenzenta w geopolityce nie jest ,zewnętrznym pótksiężycem” (!), tylko „,Wyspa-Świata”, nazwą własną, wprowadzoną przez Halforda Mackindera w 1904 r. w odniesieniu do połączonej masy lądowej Eurazji i Afryki. Tymczasem cytowane przeze mnie w książce pojęcie Island World (nie World Island), które przytaczam za M. Baczwarow, A. Suliborski, Kompendium wiedzy o geografii politycznej i geopolityce, Warszawa 2003, oznacza: zewnętrzny pótksiężyc (ang. Outer Crescent), czyli Świat Wysp (ang. Island World) i Ocean Światowy, w skład którego wchodza obie Ameryki, Australia i Japonia. W dużym uproszczeniu cały bój toczy się o to, że wg recenzenta (a także innych autorów) Heartland utożsamiany jest z World Island (Światową Wyspą), w jej otoczeniu znajduje się Inner Crescent, a dalej Outer Crescent. Wg cytowanych przeze mnie autorów również mamy Heartland, do którego ,przylega” Inner Crescent, a dalej Outer Crescent, który z kolei nazywają Island World (Światem Wysp).

W sumie mamy więc ten sam obraz geopolityczny świata, tylko niektóre jego elementy są nieco inaczej nazywane. Rozumiem, że to, co i jak zostało w geopolityce teoretycznej nazwane, ma ważne znaczenie, ale z pewnością głównie dla teoretyków-geopolityków. Dobrze by było, jednak, aby główne kwestie między sobą uzgadniali. Dziwić może, że recenzent cytując w swoich pracach Kompendium Boczwarowa i Suliborskiego, nie zauważył różnic w nazewnictwie, które teraz określa, jako „rażące błędy”.

No, ale to są z pewnością kwestie poważnych dociekań naukowych. Tymczasem realna polityka i tzw. geopolityka stosowana pozostaje dla nas śmiertelników, w tym byłych polskich oficerów sił zbrojnych, niedorównujących poziomem tym w krajach takich jak Włochy, Francja czy Rosja. 